\title{
ART INTO LANDSCAPES: NEW AUSTRALIAN IMAGES THROUGH B RITISH EYES
}

"The anxiety of our era has to do fundamentally with space, no doubt a great deal more than with time. Time probably appears to us only as one of the various distributive operations that are possible for the elements that are spread out in space."

(Michael Foucault, 1967, Berlin lectures)

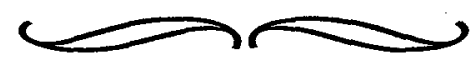

$\mathrm{T}_{\mathrm{h}}$ he Honourable Walter J. James, Lord Northbourne, devoted the inaugural Charlton Lecture, delivered in October I9I9, to tracing the emergence of the modern landscape tradition in European art. He argued that

'Landscape in its wider sense appeals in some degree to most people, and probably affects all, whether they be aware of it or not, yet as a subject for representation or interpretation by the artist it comes chronologically, comparatively late into its own, and the pictorial treatment appears to be the product of advancing civilization. In all European art the depiction of landscape remains comparatively primitive long after the artists have attained to a high degree of skill in their treatment of the human figure'1

His interpretation of what constitutes landscape art is predicated on a structural analysis of pictorial space. In this sense, if a painting can be divided into a foreground space and a background space, then by the Renaissance period,
James argued, a landscape could occupy the background where with "charm due principally to naivety and childlike simplicity' ${ }^{2}$ it complemented the sophisticated figurative compositions of the foreground. It was only when the landscape became the subject of the foreground space 'as a product of advancing civilization', that in James's categories we could speak of true landscape art.

Both the physical landscape and landscape art can be described as being structured by history. Eric Hirsch, approaching the landscape from an anthropological perspective, draws a distinction between a 'foreground', as designating the here and now, an actuality of place, and a 'background', which falls into the realm of potentiality, the horizon and the more abstract understanding of space. ${ }^{3}$ The duality within the landscape can also be related to the historian Paul Carter's notion of spatial 
history. This can be interpreted as a process of claiming through the use of language the foreground actuality and relating it to the background potentiality.

Carter writes 'In the seventy years or so after the First Fleet's arrival, the Australian landscape was mapped --even discovered, since it was not until Flinders circumnavigated Australia in $180 \mathrm{or}-2$ that it was established as a discrete and single land mass; the Australian interior was explored, its map-made emptiness written over, crisscrossed with explorer's tracks, gradually inhabited with a network of names; the Australian coastal strip, especially between the Great Divide and the sea, was progressively furrowed and blazed with boundaries, its estuaries and riverine flats pegged out for towns. The discoverers, explorers and settlers-and they were often one and the same person -were making spatial history. They were choosing directions, applying names, imagining goals, inhabiting the country.'

Like the discoverers, explorers and settlers, early Australian landscape artists, (again they were frequently either the same people as the explorers or at least travelled with them), claimed the landscape by visually recording it. The Anglo-Australian artist, S.T. Gill, who had arrived in South Australia from

Plymouth in 1839 , travelled with the John Ainsworth Horrocks expedition in I 846 in search of suitable grazing land in the Lake Torrens region. He published his account in the same year in the South Australian Gazette and Colonial Register under the title 'Progress of Discovery-
FIGURE I

S.T. Gill, 'Spencer's Gulffrom

- Flinders Range, August 1o, 1846 , watercolour, $184 \times 314 \mathrm{~mm}$

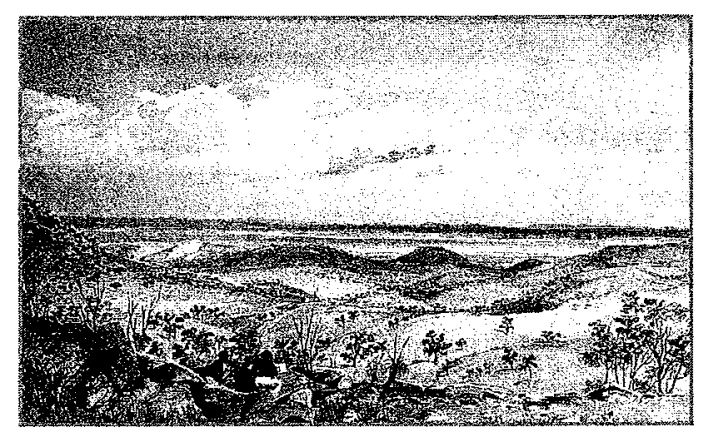

Expedition to the north-west.5 ${ }^{5}$ On the eve of his departure he explained that he was travelling 'as an amateur [explorer] for the purpose of filling his note book' and on his return he wished 'to give a full, true and accurate report of his adventures with ... faithful scenic representations. ${ }^{\prime}$ Gill's faithful scenic representations almost invariably cast the human activities within the foreground space of actuality and these are shown against a distant background of largely unexplored potentiality. In the foreground space we are presented with the mechanics of exploration-scenes of making camp, of explorers seated around a campfire, of surveying the terrain, of meetings with the natives and with the exploits of hunting. The depictions are all annotated with detail inscriptions which chart the exact location of each scene and with the precise date. These are also cross-referenced to the written diary accounts. The foreground space is an actuality which is given specificity through word and image, the words record that the image 
was done, while the image frequently records the veracity of the words. We are presented with the visual evidence of Horrocks shown in the act of exploring and on several occasions the artist depicts himself in the act of taking the views. The background deals with the unknown and the unknowable, it is the space outside the known and claimed foreground. It is interesting to note that when Gill recreated these scenes in the I $85^{\circ}$ s, after he had shifted to Melbourne, the foreground narratives remained essentially fixed and unaltered, it was tangible reality with its own historical narrative, while the background was something fluid and pointed to the realm of the imagination.

While much of the contemporary written account of this exploration deals with encounters with 'hostile natives', it was in fact the combination of two props brought along by the explorers themselves, the camel to carry supplies and a shot gun, which lead to fatal unravelling of the expedition. Horrocks decided to shoot a bird as a specimen and while loading his gun for this purpose, the camel lurched unexpectedly and the weapon accidentally discharged, wounding the explorer fatally. In the three weeks which Horrocks spent dying, amongst his final words he uttered '[Gill] has taken several sketches of this country which will show those interested how very impossible it is that any stations can be made to the west of Lake Torrens. ${ }^{7}$ Despite the truth and accurateness of the depictions, not only did Gill's imagery have a specific political agenda, but the landscape conventions of painting which he employed, the picturesque, itself carried with it a considerable ideological baggage. ${ }^{8}$ The landscape which was recorded in words and in images was historically structured and engaged a whole series of competing discourses.

Social geographers have long argued that 'while the contents of landscapes and places may be unique, they are nonetheless the products of common cultural and symbolic systems. Intersubjective intentions and experiences may be thought of as embodied in the physical environment; and interpretable through a sympathetic reading of its cultural landscape. ${ }^{9}$ In a similar way, a painted land scape is essentially a cultural image 'a pictorial way of representing or symbolizing surroundings. ${ }^{10}$ With painted landscapes the intersubjective intentions also compete with the discourse of the formal requirements of the pictorial conventions employed by the artist. In nineteenth-century Australian landscape painting, notions of the picturesque or of the sublime carried with them their own repertoire of painted strategies. ${ }^{11}$

The pluralism of artistic strategies in recent twentieth century art has generally shifted the emphasis from the representation of the landscape to an analysis of the beholder's perception of landscape and the analysis of this perceptual process. If in the nineteenth century 
the perception of the physical landscape became predicated on the viewer recognizing it as such from painted examples, ${ }^{12}$ in much of landscape art of the second half of the twentieth century, this representational nexus is broken. The landscape architect Gina Crandell notes 'modern artists no longer produce illusions that attempt to convince us they are natural views. Instead they demand that traditional pictorial conventions be measured against the actual experiences of the landscape. The focus of modern painting is blurred, their aim has turned I8o degrees, their subject has changed: it is no longer the view 'out there'; instead, it is the perceptual experience of the spectators themselves. The emphasis is on seeing rather than on what is seen.' ${ }^{13}$

Once the requirements of the mimetic role of landscape art had loosened, increasingly the artistic focus shifted to the unexplored background potentiality which could then be shaped as an armature to carry a host of personal anxieties. In British art, Paul Nash, Graham Sutherland and David Bomberg used this landscape of anxiety through which to graft formal elements drawn from Surrealism onto recognizable landscape elements. In the Australian experience, the apocalyptic landscapes of early Arthur Boyd, Peter Purves Smith and Russell Drysdale, also employed a recognizable Australian setting to express personal, as well as broader social anxieties.

Contemporary British-born artists, who trained in Britain and who tackle the
Australian landscape, unlike their predecessors, are no longer constrained by the strict representational function of landscape art. Three such artists, David Blackburn, Mary Husted and John Wolseley, while all rejecting literalness of depiction as an end in itself, can be viewed as exploring three different directions in landscape art within essentially a postmodernist context. David Blackburn, who for the past twenty-five years has divided his time between Yorkshire and Australia, has found in the Australian landscape a metaphor for an inner spiritual life, an escape into a visionary landscape tradition. Details found within a foreground space are taken out of a fixed actuality and are projected into the background distance giving them the quality of a changing dream caught within a constant process of metamorphosis. John Wolseley, who settled in Australia in 1976 , has set out to systematically study the workings of nature, the mind of the environment. Through a precise empirical investigation of the processes of nature, he has sought to comment on global changes. Mary Husted, a Welsh artist, is a relatively recent visitor to Australia, who in her constructions and installations sets out to create her own personal spatial geography of the Australian landscape.

The visionary tradition of landscape painting, associated with the work of David Blackburn, may be interpreted as one largely preoccupied with a background potentiality, where anxiety points 
to a path of spiritual escape. While the paintings of late Turner, William Blake and Samuel Palmer all contain elements of this landscape vision, and ultimately its general origins may be traced back to the Northern European Romantic tradition of landscape painting and printmaking, ${ }^{14}$ the visionary landscape moved in a new direction in the twentieth century when the mandatory links with a representational reality had largely disappeared.

David Blackburn, an Anglo-Australian artist, ${ }^{15}$ recalled recently: 'I was born in Huddersfield and remember as a child living alongside engineering works which I perceived as grim, grey and ugly, and yet one could gaze at fields and woods intensely green across the valley.' ${ }^{\prime 6}$ In a sense this can be interpreted as an awareness and conscious rejection of the foreground actuality and the search for an escape in the potentiality of the background vision. Just before

FIGLRE 2

David Blackburn, Pale stones in light', rg95, pastel, ,508 $x 616 \mathrm{~mm}$,

Private Collection, $L / K$

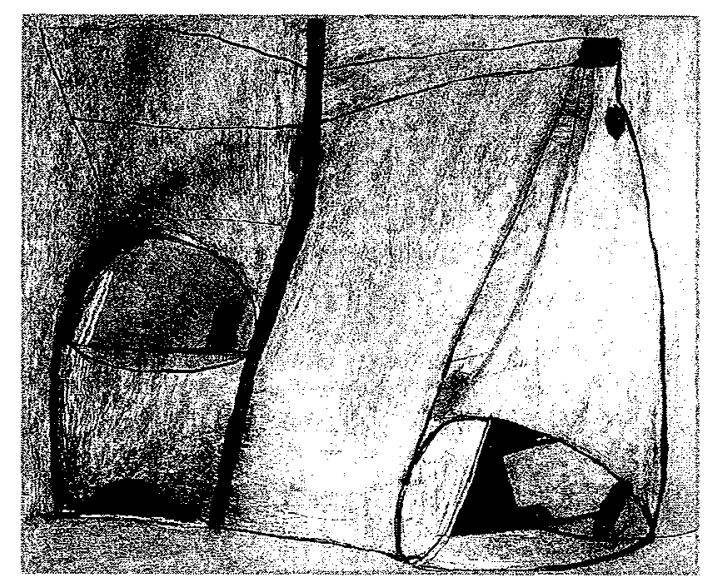

his twenty-fourth birthday, in June $\mathrm{r} 962$, David Blackburn arrived in Australia for the first time. He had behind him a thorough and somewhat traditional training from the Huddersfield School of Art and from London's Royal College of Art. Earlier he had met the Austrian expressionist artist Gerhardt Frank ${ }^{17}$ who had introduced him to pastels, a medium to which he subsequently devoted virtually all of his creative energies.

The three years and a bit which David Blackburn spent in Australia during his first visit were devoted to matching pictorial schema which he brought with him from Britain with the experience of the Australian reality. At the time, his letters back home were permeated with a euphoric enthusiasm for the Australian landscape and expressed an admiration for the exotic scenery and the new qualities of light and colour. Although he found the new quality of light a revelation and was struck by the scenery he encountered in Central Australia, on the Nullarbor, in the west and in Queensland, the drawings and prints which he made during this period reflected little of this and were essentially dark and almost monochromatic. It was as if he was overwhelmed by the vastness of the background potentiality and working primarily in black chalk, he concentrated on biomorphic studies taken from small precise elements in the very foreground space of nature. The gnarled shape of roots, designs which grasses made on sand, the bark on trees and the brittle 
broken pattern of leaves made up a major part of the iconography of his first Australian exhibition. The focus was on minute details which disguised both the sense of scale and their relationship to the whole.

The single major series of work to emerge from the three-year period which David Blackburn spent in Australia was the black pastel twenty-one panel The Creation series. In a way this was a juvenile work of high

Romanticism, rich in literary allusions and drawing on visual sources as diverse as Leonardo's drawing of man as the measure of all things and William Blake's haunting image of The Ancient of Days. It was also a series which grappled with several of the central concerns in his oeuvre, that of metamorphosis, polarities of light and darkness, and the question concerning the passage of time. In terms of the Australian landscape, it, more than anything else, marked his inability to come to terms with the new forms and the new light which he encountered and which so much fascinated him. As was the case with so many of his fellow countrymen, on his first visit to Australia, David Blackburn was an Englishman in search of a familiar setting, but unlike them he did not seek out to translate his surroundings into the terms of an English reality, but sought out details through which he felt he could uncover the secret workings of nature in the Antipodes. The painters to whom he turned were essentially the Anglo-
Australian and European masters, particularly John Glover, Arthur Streeton, Tom Roberts, Conrad Martens and Louis Buvelot, who themselves were caught in the process of interpreting the Australian landscape in terms of European visual paradigms including the Claudian vision, Barbizon naturalism and the 'glare aesthetics' of Orientalism.

When David Blackburn returned to Australia five years later in r971, he found a path through which he could reapproach the Australian landscape. The crucial factor was his meeting with Fred Williams, the Australian landscape painter who in his practice introduced the cubist structuring of pictorial space to the Australian landscape. ${ }^{18}$ Williams deconstructed the individual elements in nature-rocks, trees, stumps, hillsides and shrubs; divorced them from the European conventions of constructed perspectival space, and then reintroduced them in startlingly new configurations on a totally flattened picture plane which rejected the traditional divisions between the foreground and the background. Within this process he also rejected notions of European Picturesque compositions with their scenic focal point and created a reading of the Australian landscape which was fundamentally featureless, which had a randomness and a breathing ease, and one which had a strong sense of sitespecific authenticity. Although a number of David Blackburn's Australian works of I97I-72 reflect closely his fascination 
with Fred Williams's vision, ${ }^{19}$ this was essentially a liberating, rather than a cloning experience.

David Blackburn's most recent visit to Australia in $1995^{-} 9^{6}$, involved his first serious encounter with Aboriginal art. Almost as if in a logical progression, if Williams for Blackburn appeared to strip. the Australian landscape of its visual irrelevancies and expose its formal structural elements which could be reassembled in accordance with a new artistic schema, Australian Aboriginal artists exposed the bones of the landscape, those elements which were created at the time of the Dreaming and which are not subject to change through ephemeral elements such as surface vegetation or the changing seasons. For Blackburn's work the most significant Aboriginal artist was Rover Thomas, ${ }^{20}$ who with his fields of rich subdued colour and crisp articulated surfaces, created an authentic and convincing reading of the Australian landscape. Blackburn's visionary landscapes over the past decade have absorbed the actuality of the foreground space into a rich metaphoric vision which nevertheless retains the quality of a sense of place, but one enriched through a personal spirituality. ${ }^{21}$

Earlier this year he noted 'I try to use the landscape as a metaphor for feelings, to use the recognizable outer world as a means of giving form to my inner life-my visions, fantasies, sense of the spiritual. The fact is that an object or a landscape can have several realities. For instance, a drawing may suggest a cliff or a quarry, a flower-head or an oriental bowl, or an estuary seen from the air. The forms dissolve into each other like images in a film. I am trying to allude to many things rather than simply to describe one particular reality. The drawings develop as much from each other as from the landscape itself so that the reality comes as much from my own internal landscape as from any external topography.'

If David Blackburn was born essentially into a family with no artistic connections or pretentious and then found his own path into the visionary landscape tradition, John Wolseley was born in England in 1938 into a family steeped in artistic traditions and has spent much of his life in attempting to repudiate this heritage. His father, Garnet Ruskin Wolseley, was a tonal realist painter, a prize-winning Slade School artist, who was part of the Newlyn artists' colony, and who was an amateur archaeologist who championed the ideas of John Ruskin and was generally hostile to most manifestations of modernism. John Wolseley, after a traditional training at Byam Shaw and then at the St Martin's School of Art in London, turned his back on tonal realism and immersed himself in post-war modernism in Paris where he worked for eighteen months with the English modernist printmaker, S.W. Hayter at Atelier 17 . What he shared in common with his father was an enormous visual curiosity, a nomadic predisposition and the habits of a data-gathering magpie. 
In an attitude to art most clearly expressed in the writings of Leonardo da Vinci, the landscape and nature are not considered as static entities which simply exist, but they are viewed as part of a process which is constantly in a state of change and the role of the artist is to try to decipher this process. Leonardo, for example, writing notes to himself about observing sand dunes, noted: 'Describe the mountains of 'flexible dry things'. Treat that is of the formation of the waves of sand borne by the wind, and of its hillocks and hills as it occurs in Libya; you may see examples in the great sand banks of the Po and the Ticino and other large rivers.' In another place he noted 'If the earth of the antipodes which sustains the ocean rose up and stood uncovered far out of this sea but being almost flat, how in process of time could mountains, valleys and rocks with their different strata be created? The mud or sand from which the water drains off when they are left uncovered after the floods of the rivers supplies an answer to this question... ${ }^{.22}$ Exactly five hundred years later, John Wolseley was to revisit similar themes. In 1993 he observed: 'I have been trying to understand sand dunes-their layering, their rhythms and movements and their cyclic developments which have the structure and elegance of a complex mathematical theory. Often I have been camped in the swale of some huge longitudinal dune and during the night, the wind from some unusual quarter has quarried down
FIGURE 3

John Wolseley, 'The dune remains the same, only the margins change', rgg2/g3, lithograph, $650 \times 940 \mathrm{~mm}$, Private Collection

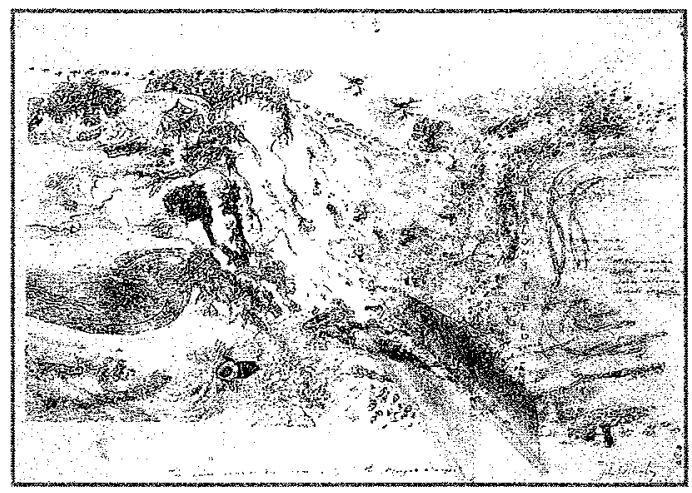

through several strata of sand and revealed hidden layers of great antiquity - say a thousand year old camp of the Wanganuru people. Or revealed the geography of an older dune system which in turn may cover the fossilized remains of a Pleistocene forest. I have been looking upon these layered 'archaeologies', these gold and red piles of different histories and systems as a metaphor for the human psyche; the way each of us could be seen as a walking many-layered world of passions, ancestral memories, neuroses, genetic patterns and ancient archetypes. ${ }^{.23}$

The American geographer, John Kirtland Wright, coined the term 'Geopiety' which married the Greek root for 'earth' with the Latin 'piety', as an expression of reverence for the earth and the planet. ${ }^{24}$ Yi-Fu Tuan has extended this meaning to include the compassionate urge to protect the fragile beauty and goodness of life against its enemies, not the least of which is time. ${ }^{25}$ John Wolseley's attitude 
to the environment can be seen to fall within the broad parameters of geopiety. He seeks not only to empirically observe and record the landscape, but also to actively interact with it. He noted recently When leaving a favourite place I have been in the habit of making a drawing and burying it by my camp... I will usually return a year or two later. One half of the drawing is still preserved pristine in my portfolio, but the part I exhume maybe changed in the most varied and mysterious ways according to the habitat. Waves of colour, stains, crystalline mosaics, specklings, dapplings, all hint at unknown agencies. There are traces of unseen movements and events which fall through the sand above the drawing as it lies in its silent resting place. ${ }^{.26}$

In the last few years John Wolseley has been concerned with tracing the breakup of the supercontinent of Gondwana as it drifted apart into the continents of Australia, South America, Antarctica, Africa and India. By examining in great detail the tiny spores, pollen, seedpods and lichen in Tasmania and Patagonia, he establishes, what Paul Carter refers to in his essay 'The Anxiety of Clearings', the feeling that of 'an uncanny sense of having been here before. ${ }^{27}$ The details of the foreground space, gathered with an empirical accuracy, form a microcosm through which to tackle the potentiality of the macrocosm. While tracing the move-ment of continents based on evidence left within a fragile environ- ment, John Wolseley's art engages with conservation issues and tackles the forestry industry giants and their senseless destruction of the Australian native forests. Although his work celebrates the timeless scribblings of glaciers; it also refers to the anxiety of vanishing spaces. He writes in a catalogue $I$ have several times returned to a site to finish a painting and found my gaze meets earth ravaged and denuded. Often there are rows of partly burnt debris and the area has been scorched, ploughed or ripped. ${ }^{28}$ When Mary Husted first came to Australia in 1989 , it was not so much with a feeling that she had been here before, but with an overwhelming sensation that she had arrived into a landscape which she could traverse and claim as a personal topography, a landscape through which she could establish her own identity. Born in Leicester in England in I944, as the second of two twins, her mother died at childbirth apparently having seen the first daughter, Roma, but not Mary. Questions of her identity, her relationship to her mother, whom she never knew, and to her aunt who brought her up, and to her Welsh and English ancestry, have been central to her life and art. Like David Blackburn and John Wolseley, the natural landscape, ever since her childhood, has been a place of refuge and escape, a place where one could both lose oneself and find oneself.

Her constructed black boxes of landscape, like little islands of spatial anxiety surrounded by mirrors, convert the 
viewer into a voyeur, who is invited to peer into ambiguous spaces which are loaded with visual clues. No matter how persistent the inquirer, the palimpsest which she builds up in her work does not permit a rational decipherment, the enigma of identity and questions concerning the nature of the landscape experience are forever present and remain unanswered. She creates a labyrinth of associations and a series of physical visual hurdles which the beholder needs to overcome to enter into her constructed landscape spaces.

After the world at large was convinced that the artist had retired from active art

FIGURE 4

Mary Husted, 'To some extent shared', (detail) rgg7, mixed media, collage on board with glass, $1860 \times 75^{\circ} \mathrm{mm}$, Private Collection, $U K$ making, Marcel Duchamp, somewhat secretively, in a studio loft in New York spent the last two decades of his life, from 1946 to 1966 , working on an installation landscape to which he gave the title 'Étant Donnés: I) la chute d'eau, 2) le gaz d'éclairage... ${ }^{.9}$ Now housed in the Philadelphia Museum of Art, it is one of the most famous and enigmatic works in the entire history of twentieth-century art. No matter how closely one peers through the pair of holes in the weathered wooden Spanish door, framed by a brick archway, the image remains mysterious and partly concealed. In the background there is a flowering garden of fecundity which is reproduced in the slightly garish colours resembling a cheap r93os picture postcard. The focal point of the background is a kinetic waterfall, which appears almost like an

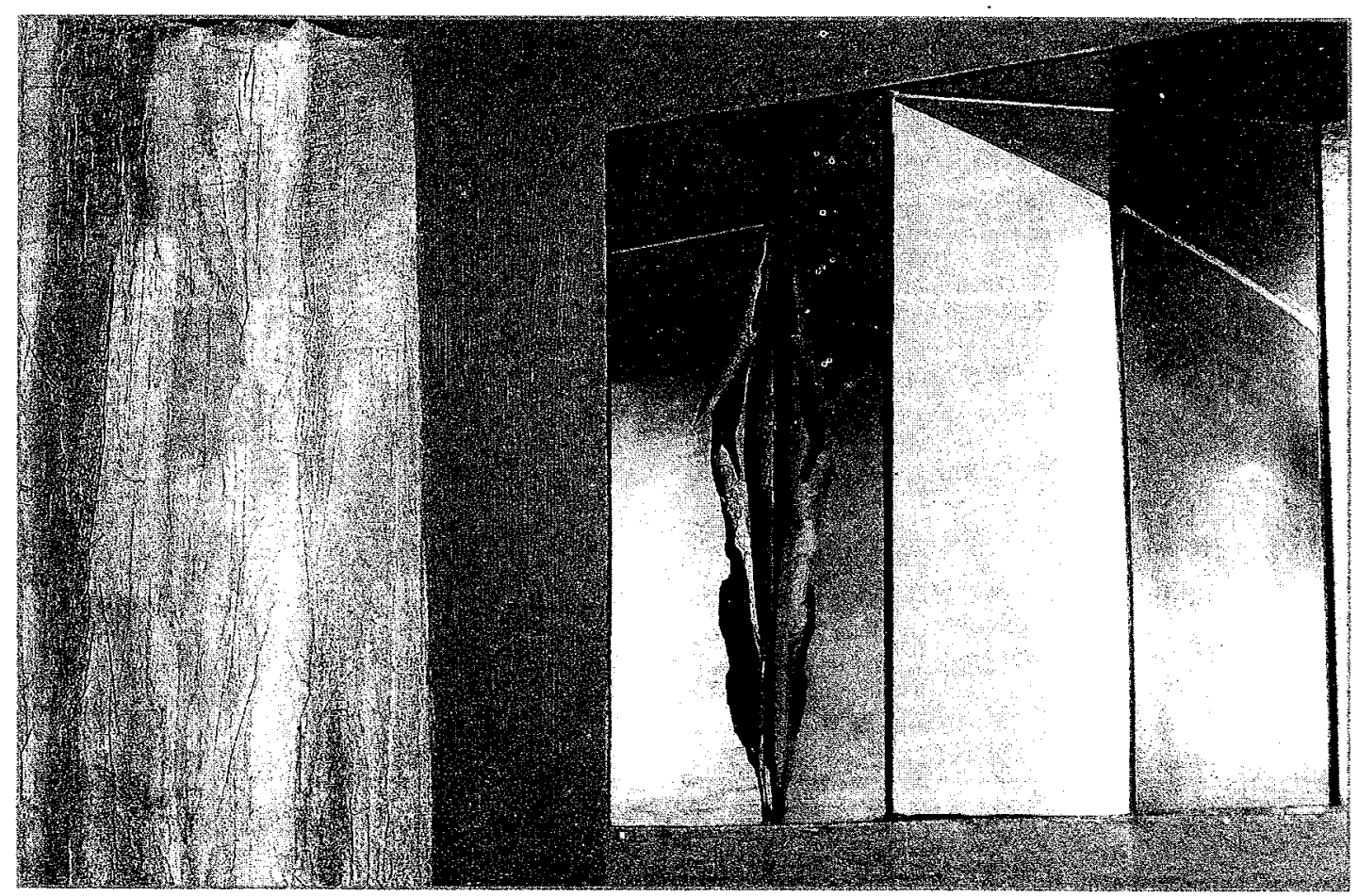


abstracted and unattainable image of a heavenly utopia. It is a landscape of fantasies and potentiality. In the foreground, seen through a gap crudely punched out of a brick wall, lies a naked woman's torso with erotically splayed out legs. She is cast against an autumnal setting, which is barren and desolate, the branches are bare and prickly. The potential for the voyeuristic pleasure of the experience is subverted by the sensation that we are witnessing a scene of violence and violation. Yet no matter how intently we peer through the tiny apertures, we can never catch a glimpse of the woman's face, the sole clue as to her identity is the lock of blond hair which

somewhat carelessly lies near her bosom. The reading of this foreground space, the traditional specificity of the here and now actuality, as a scene of carnage or human sacrifice, is complicated by the fact that the nude is shown holding a burning lantern which illuminates the space, almost in a gesture of triumph or defiance. Duchamp casts a set of clues which automatically engage the beholder, but which in their nature are irreconcilable.

Mary Husted's small installed landscapes conceptually relate to the formal strategies employed by Duchamp, however their intent and purpose are different. Her boxes of memory create a deceptive space (where the sense of ambiguity is heightened through the use of mirrors) and where the cryptic clues refuse to point to accessible solutions. However, unlike Duchamp who claimed that there was no solution as there was no problem, Mary Husted's compositions point to a set of questions and propose solutions, but in each instance vital elements in this jigsaw are missing. The landscape which she constructs is both real and tangible, but it is encoded as a personal topography. Within this landscape she has created her own spatial forms and idiosyncratic fantasies, through this symbolizing both her surroundings and her imagined place within them. Photographic images of herself as a child, her sister, mother and aunt, in some pieces are collaged into the darkened surfaces and are combined with trophies from nature, leaves, twigs and feathers, themselves encoded symbols of a mysterious landscape.

Physical landscapes, landscapes of the mind and landscapes in art are all structured by history, are all, in one sense or another, cultural images which represent and symbolize their surroundings.

SASHA GRISHIN

Sasha Grishin is a Reader in the Department of Art History, $A N U$ and is curator of the exhibition New Australian Images through British Eyes: David Blackburn, Mary Husted and John Wolseley which will open at the ANU Drill Hall Gallery, Canberra on September 4 and will continue until October 5, rg97. 


\section{REFERENCES}

1 Walter J. James, "The development of modern landscape', in Charlton Lectures on Art, Clarendon Press, Oxford I925, P II

2 Ibid., p I3

3 Eric Hirsch 'Introduction', in Eric Hirsch and Michael O'Hanlon (eds.) The Anthropology of Landscape: Perspectives on place and space, Clarendon Press, Oxford I995, P 4

4 Paul Carter, The Road to Botany Bay: An essay in spatial history, Faber and Faber, London 1987 , pp xx-xxi

5 Keith Macrae Bowden, Samuel Thomas Gill:Artist, Hedges and Bell, Maryborough i97i, pri4

6 South Australian Register, 4 July I 846, p $2 d$ and South Australian Register, 15 July r 846 , $3 \mathrm{e}$, both quoted in Ron Appleyard et al. S.T. Gill: The South Australian years I839-1852, Art Gallery of South Australia, Adelaide I986, p 86; Sasha Grishin, 'S.T. Gill: Defining a landscape', Voices, vol 2/4 (r992-93), pp 5-19

7 Bowden; op. cit., P I7

8 For example, see Ann Bermingham, Landscape and Ideology: The English rustic tradition, I740-I860, University of California Press, Berkeley i986, pp 57-85; John Barrell, The Dark Side of the Landscape: The rural poor in English painting $1730-1840$, Cambridge University Press, Cambridge 1980
9 Peter Jackson and Susan J. Smith, Exploring Social Geography, Allen and Unwin, London I984, Pp 43-44

10 S. Daniels and D. Cosgrove (eds.), The Iconography of Landscape: Essays on symbolic representation, design and use of past environments, Cambridge University Press, Cambridge I988, p I

11 Tim Bonyhady, Images in Opposition: Australian landscape painting $I_{80} \mathrm{I}_{-}^{-}$ I8go, Oxford University Press, Melbourne 1985

12 Keith Thomas, Man and the Natural World: Changing attitudes in England 1500-1800, Penguin, Harmondsworth 1984

13 Gina Crandell, Nature Pictorialized: 'The view' in landscape history, Johns Hopkins University Press, Baltimore I993, p. I6r

14 Robert Rosenblum, Modern Painting and the Northern Romantic Tradition, Thames and Hudson, London I975; Keith Hartley (ed.) The Romantic Spirit in German Art I79o-Iggo, Scottish National Gallery/Hayward Gallery, London 1994

15 David Blackburn was born in Huddersfield in Yorkshire in 1939 and has lived for seven prolonged periods in Australia between I963-66; r97172; 1973-74; 1977-78; 1980-8I; I984 and $1995^{-9} 6$. He is included as an Australian artist in all editions of McCulloch's Encyclopedia of. Australian Art. See for example Alan 
and Susan McCulloch, The

Encyclopedia of Australian Art, third edition, Allen and Unwin, St Leonards I994, $\mathrm{P9} 2$

16 David Blackburn, artist's statement April 1997.

17 Gerhardt Frankl (Igoı -65)

18 James Mollison, $A$ Singular Vision: The art of Fred Williams, Australian National Gallery, Canberra I989; Patrick McCaughey, Fred Williams I927-1982, Bay Books, Sydney 1987

19 Sasha Grishin, David Blackburn and the Visionary Landscape Tradition, Hart Gallery, London [r994], p $22 \mathrm{ff.}$

20 Wally Caruana, Aboriginal Art, Thames and Hudson, London r973, p I64 ff.;Rover Thomas et al, Roads Cross: The paintings of Rover Thomas, National Gallery of Australia, Canberra I994

21 David Blackburn, artist's statement, April 1997

22 Edward MacCurdy, The Notebooks of Leonardo da Vinci: Arranged, rendered into English and introduced, vol I, Jonathan Cape, London 1958 [1938], pp 346, 295

23 John Wolseley, artist's statement in catalogue Paintings, Lithographs and
Sedimentary Prints from the Simpson

Desert by John Wolseley, Rex Irwin, Sydney 1993 np.

24 John K. Wright, Human Nature in Geography, Harvard University Press, Cambridge, Ma., I966, pp 250-85

$25 \mathrm{Yi}-\mathrm{Fu}$ Tuan, 'Geopiety: A theme in man's attachment to nature and place', in David Lowenthal and Martyn J. Bowden (eds.) Geographies of the Mind: Essays in historical geosophy, Oxford University Press, New York I976, P 34

26 John Wolseley, artist's statement in To the Surface: Contemporary landscape, Plimsoll Gallery, Centre for the Arts, Hobart I993, p 29

27 Paul Carter, 'The Anxiety of Clearings', in exhibition catalogue John Wolseley: Patagonia to Tasmania: Origin movement species tracing the southern continents, Queen Victoria Museum and Art Gallery/University of Melbourne, Melbourne ig96, np.

28 John Wolseley, 'Endnote ... and a conclusion? A conversation between John Wolseley and Tim Cadman', in Ibid., np

29 In English: 'Given: I) the waterfall, 2) the illuminating gas...'

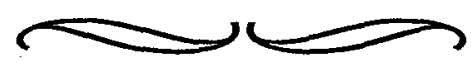

